\title{
БИОЛОГИЯ
}

УДК 598.2(502.63) (28):591.526 (571.5)

DOI: $10.18101 / 2542-0623-2019-4-7-34$

\section{ЛИМИТИРУЮЩИЕ ФАКТОРЫ И УСПЕШНОСТЬ РАЗМНОЖЕНИЯ ОКОЛОВОДНЫХ И ВОДОПЛАВАЮЩИХ ПТИЦ В УСЛОВИЯХ ГОРНО-ПОЙМЕННОГО ВОДНОГО РЕЖИМА В ДЕЛЬТЕ Р. СЕЛЕНГИ (ВОСТОЧНАЯ СИБИРЬ)}

\section{Ю. И. Мельников}

(C) Мельников Юрий Иванович

кандидат биологических наук,

Байкальский музей Иркутского научного центра,

Россия, 664520, Иркутская обл., пос. Листвянка, ул. Академическая, 1

E-mail: yume148@mail.ru

На основе многолетних работ (1972-1985 гг.) выяснены состав и сила воздействия лимитирующих факторов, определяющих успешность размножения прибрежных птиц в дельте p. Селенги (оз. Байкал). Долина р. Селенги относится к регионам с четко выраженным горно-пойменным водным режимом. Очень сильные перепады уровней воды на протяжении одного гнездового сезона между периодами яйцекладки и вылупления птенцов приводят к значительной гибели кладок, что резко снижает успешность гнездования птиц. Лишь использование специальных адаптаций (достройка гнезд, повторное размножение и динамичная пространственная структура) позволяет птицам поддерживать уровень размножения, достаточный для поддержания среднего уровня численности птиц, характерного для данного региона. Однако выяснение этих особенностей размножения птиц требует очень много времени и специальной трудоемкой и продолжительной работы, нередко с использованием специальных экспериментов и достаточно сложных методологических подходов. Нами такая работа выполнена на протяжении малого (11-летнего) внутривекового цикла климата в 1973-1982 гг. Данные материалы, по ряду причин, до сих пор не были опубликованы. Между тем для организации дальнейших углубленных исследований экологии околоводных и водоплавающих птиц крайне необходим специальный и детальный анализ предыдущих исследований такого уровня. Работа выполнена на ключевом участке

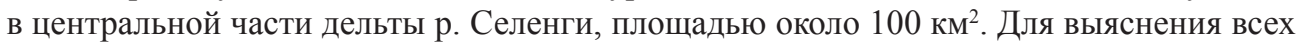
параметров гнездового цикла птиц использовался контроль гнезд на учетных площадках (через 2-4 дня) разной площади и конфигурации, но не менее 1,0 га. Он позволял точно фиксировать гибель яиц в кладках и появление новых гнезд. Выявлены основные лимитирующие факторы, определяющие успешность гнездового сезона разных видов птиц в условиях горно-пойменного водного режима. Уровень их воздействия значительно изменялся у разных видов и по сезонам, но основная гибель яиц связана с колебаниями уровня воды (2,3-42,1 \%) и хищничеством птиц (2,8-41,3\%). В отдельных случаях существенное значение могли иметь антропогенные факторы: выжигание растительности, выпас скота, сенокошение и беспривязное содержание пастушеских собак (2,0-20,0%). Общая гибель яиц у разных видов по сезонам составляла 29,8-75,8 \% и была связана с размером конкретного вида и особенностями его экологической ниши. Однако потери яиц у колониальных птиц явно были ниже, чем у неколониальных видов. Выживание 
вылупившихся птенцов было выше, чем кладок: неколониальные виды - 60,9-92,2 \%, колониальные виды - 59,6-86,5 \%. Несомненно, выживаемость птенцов у колониальных видов была ниже, чем у неколониальных птиц. В данном случае на первое место среди лимитирующих факторов выходят биотические факторы и, прежде всего, воздействие разных видов хищников. Наибольшее воздействие, без сомнения, оказывают пернатые хищники, прежде всего факультативные: монгольская Larus (vegae) mongolicus и сизая L. canus чайки, восточная черная ворона Corvus corone orientalis и очень редко сорока Pica pica. Несомненно, социальная напряженность в колониях из-за большой плотности гнездования птиц ведет к повышенной гибели птенцов. Общая успешность размножения, рассчитанная на основе средневзвешенной по всем изученным видам колониальных $(46,9$ \%) и неколониальных $(37,9$ \%) птиц очень близка, но в целом у колониальных видов она выше на 9,0 \%. Обсуждаются преимущества и недостатки колониального типа гнездования по сравнению с неколониальными видами птиц.

Ключевые слова: околоводные и водоплавающие птицы; гнездовой период; лимитирующие факторы; величина гибели гнезд и птенцов; успешность размножения.

\section{Для цитирования:}

Мельников Ю. И. Лимитирующие факторы и успешность размножения околоводных и водоплавающих птиц в условиях горно-пойменного водного режима в дельте р. Селенги (Восточная Сибирь) // Природа Внутренней Азии. Nature of Inner Asia. 2019. № 4(13). C. 7-34. DOI: 10.18101/2542-0623-2019-4-7-34

Лимитирующие факторы в гнездовой период включают все причины смертности и определяют особенности гнездования популяций различных видов птиц и, прежде всего, общую успешность их размножения. Поэтому выявление их состава и определение силы влияния каждого из них в конкретных ситуациях гнездовых сезонов являются важной задачей любого исследования, направленного на выяснение уровня воспроизводства птиц конкретного региона. Считается, что колониальные птицы имеют явные преимущества перед другими видами околоводных птиц при гнездовании в одних и тех же условиях среды. Однако данный вывод очень спорен и работ, посвященных выяснению данной проблемы, очень мало и они часто методически не выдержаны, поскольку сравнивалась успешность размножения птиц, выявленная в разных регионах. В то же время такие регионы часто имеют специфические наборы лимитирующих факторов и, соответственно, разные уровни гибели яиц и птенцов. Сравнение успешности размножения птиц в таком случае не поможет выявить преимущества одного типа гнездования относительного другого, особенно если такие различия не достигают большой величины. Мы собирали материал по данным группам птиц одновременно в одном и том же регионе, что позволяет провести полноценные сравнения этих типов гнездования. В данной работе приводятся сведения и обсуждаются полученные материалы многолетних исследований (1972-1985 гг.) в дельте р. Селенги (оз. Байкал) - основном гнездовом районе прибрежных птиц Восточной Сибири.

\section{Район работ, материал и методика}

Дельта р. Селенги отличается сложным составом и сезонной динамикой лимитирующих факторов природного и антропогенного происхождения. Полная характеристика района работ и основные методы исследований детально обсуждались 
Ю. И. Мельников. Лимитирующие факторы и успешность размножения околоводных и водоплавающих птиц в условиях горно-пойменного водного режима в дельте...

в нескольких публикациях разных авторов [Скрябин, 1975; Мельников, 1977; 1979; 1981; 1982; 1987; 2006; 2007a; 2009; 2010а; 2010б; 2011б; 2018; Шинкаренко, Подковыров, 1979; Иметхенов, 1994; Фефелов и др., 1995; 1996; 2001; Подковыров, 1997]. В нашем случае большой объем собранного материала обусловлен высокой долей гнезд колониальных видов, находящихся под постоянным наблюдением. Кроме того, в условиях дельты р. Селенги многие неколониальные виды птиц формируют крупные локальные гнездовые агрегации (от нескольких десятков до сотен гнезд), что значительно облегчает сбор массового полевого материала [Мельников и др., 1984; Мельников, 2000; 2006] (табл. 1).

В то же время мы считаем необходимым специально указать на некоторые наиболее важные природно-климатические характеристики этого региона, а также методы сбора материала. Прежде всего, для дельты р. Селенги характерен горно-пойменный водный режим, с сильным, но коротким весенним половодьем и несколькими летними паводками (от 2 до 7) [Мельников, 2018]. Они вызываются либо продолжительными (2-4 дня) обложными, либо ливневыми (за несколько часов выпадает месячная и более норма осадков) дождями, а также интенсивным таянием снежников и ледников в горах в середине лета. Паводки иногда достигают уровня катастрофического наводнения. В такие сезоны практически вся дельта Селенги уходит под воду и незатопленными остаются только небольшие наиболее высокие ее участки.

Для этого водного режима характерно сильное, но короткое весеннее половодье и несколько сильных паводков в летний период (от 2 до 7). В некоторых случаях на границах 11-летних (малых внутривековых), больших внутривековых и вековых климатических циклов эти паводки имеют вид катастрофических наводнений. Такие ситуации наблюдаются при окончании тепло-сухой фазы климата одного цикла и начале влажно-холодной фазы следующего цикла [Мельников, 2018]. В соответствии с этим на протяжении климатического цикла любого уровня успешность размножения птиц меняется.

Высокая плотность гнездования прибрежных птиц в дельте р. Селенги привлекает большое количество хищных птиц. Поэтому другим сильнодействующим фактором является разорение гнезд пернатыми хищниками. Наибольший урон наносят неспециализированные (факультативные) хищники, в обычных условиях не разоряющие гнезда. Формирование участков с очень высокой плотностью гнездования птиц, включая колониальные виды, способствует переходу части особей крупных чаек (монгольской и сизой) и врановых (черная ворона Corvus corone и сорока Pica pica) на активное хищничество [Мельников, 1977; 1979; 1981; 1982; 1987; 2006; 2010в; 2012; Журавлев, 1986].

Данная ситуация усугубляется подтоплением многих гнезд. Для их спасения птицы начинают использовать одну из основных своих адаптаций - надстройку гнезд в высоту по мере подъема уровня воды [Мельников, 1982; 2006, 2012]. В это время птицами часто используется вся растительность, находящаяся вокруг гнезда (в радиусе до 5 или несколько больше метров), и его маскировка резко снижается. В результате надстройки и высокой заметности часть таких гнезд быстро обнаруживается и становится легкой добычей хищников [Мельников, 1977; 1982; 2006; 2010в; 2012]. 
Объем материала, использованного для определения состава лимитирующих факторов и успешности размножения птиц в дельте р. Селенги (оз. Байкал) $(1972-1985$ гг.)

\begin{tabular}{|c|c|c|c|c|c|}
\hline $\begin{array}{l}\text { № } \\
\Pi / \Pi \\
\end{array}$ & Вид & $\begin{array}{c}\text { Кол-во } \\
\text { гнезд }\end{array}$ & $\begin{array}{l}\text { № } \\
\Pi / \Pi \\
\end{array}$ & Вид & $\begin{array}{c}\text { Кол-во } \\
\text { гнезд } \\
\end{array}$ \\
\hline 1 & Лысуха Fulica atra & 142 & 9 & Серая цапля Ardea cinerea & 1739 \\
\hline 2 & $\begin{array}{l}\text { Азиатский бекасовидный } \\
\text { веретенник Limnodromus } \\
\text { semipalmatus }\end{array}$ & 530 & 10 & Малая чайка Larus minutus & 1882 \\
\hline 3 & Кряква Anas platyrhynchos & 437 & 11 & $\begin{array}{l}\text { Озерная чайка } \\
\text { Larus ridibundus }\end{array}$ & 2720 \\
\hline 4 & Шилохвость Anas acuta & 194 & 12 & $\begin{array}{l}\text { Монгольская чайка Larus } \\
\text { (vegae) mongolicus }\end{array}$ & 1595 \\
\hline 5 & $\begin{array}{l}\text { Чирок-трескунок } \\
\text { Anas querquedula }\end{array}$ & 58 & 13 & Сизая чайка Larus canus & 1467 \\
\hline 6 & Широконоска Anas clypeata & 157 & 14 & $\begin{array}{l}\text { Белокрылая крачка } \\
\text { Chlidonias leucopterus }\end{array}$ & 5547 \\
\hline 7 & $\begin{array}{l}\text { Красноголовая чернеть } \\
\text { Aythya ferina }\end{array}$ & 168 & 15 & $\begin{array}{l}\text { Белощекая крачка } \\
\text { Chlidonias hybrida }\end{array}$ & 367 \\
\hline 8 & $\begin{array}{l}\text { Хохлатая чернеть } \\
\text { Aythya fuligula }\end{array}$ & 142 & 16 & $\begin{array}{l}\text { Речная крачка } \\
\text { Sterna hirundo }\end{array}$ & 497 \\
\hline & & & 17 & Чеграва Hydroprogne caspia & 1307 \\
\hline
\end{tabular}

Наряду с экспериментальным изучением уровня смертности на основе мечения гнезд и всех яиц каждой кладки, а также кольцевания птенцов с постоянным их контролем [Мельников, 2011; 2012] использовались и непосредственные визуальные наблюдения. Они помогали выявлять все факторы гибели (вплоть до нападений на выводки птиц крупной щуки Esox luceus), а также уточнять характер следов, оставляемых хищниками у гнезда (прежде всего обращалось внимание на следы, оставляемые массовыми видами факультативных хищников). Это помогало точно определять причины гибели кладок, используя характерную следовую деятельность видов, разоряющих гнезда [Журавлев, 1986; Мельников, 2009; 2010б]. В данном случае имеется в виду оставление не конкретных следов, а следов деятельности: характерные выхваты гнездовой подстилки, следы на расклеванных яйцах, особенности использования содержимого яиц и т.д.

Ежегодно на специально заложенных контрольных площадках (не менее 1,0 га каждая), охватывающих все основные местообитания птиц (пропорционально их соотношению на местности), в течение всего гнездового сезона проводился поиск гнезд околоводных и водоплавающих птиц. Общее количество площадок с ежегодной учетной площадью $\sim 5,0$ км² в разные годы наблюдений колебалось от 18 в многоводные годы до 45 в маловодные сезоны (без учета колоний, обрабатываемых отдельно). В поиске гнезд принимали участие от 3-4 до 9-18 студентов иркутских вузов. Во всех случаях повторные кладки обнаруживались во время контрольных осмотров гнезд, находящихся под постоянным наблюдением. При резких изменениях экологической ситуации, приводящей к массовой гибели гнезд за короткий пери- 
Ю. И. Мельников. Лимитирующие факторы и успешность размножения околоводных и водоплавающих птиц в условиях горно-пойменного водного режима в дельте...

од (резкие повышения уровня воды), проводилось дополнительное обследование территории, не залитой водой. Обнаружение поздних колоний или поздних кладок в колониях не вызывало затруднений, поскольку при высокой интенсивности работ они легко обнаруживались во время контроля ранее зарегистрированных гнезд.

Все найденные гнезда метились пронумерованными колышками, которые устанавливались в 3-4 метрах от гнезда, с наклоном в его сторону. Яйца метились несмывающейся краской (КЦ-52) полосками (чайки и кулики) или римскими цифрами (пастушки и утки) на узком конце яйца, количество или значение которых соответствовало порядку их откладки, определяемому флотационным методом [Онно, 1975; Мельников, 2006; 2011a; 2014]. Контроль гнезд проводился через 2-3 дня и, как исключение, в периоды ненастной погоды через 4 дня вплоть до конкретного финального состояния: гибели кладки по различным причинам или вылупления и выращивания птенцов.

Ранее, для определения степени насиженности яиц и расчета дат их откладки, при изучении экологии охотничьего фазана Phasianus colchicus был предложен специальный метод - водный тест [Westerskov, 1950], получивший широкое распространение среди исследователей гнездовых циклов птиц. В настоящее время после специальной апробации и доработки для конкретных видов птиц он используется практически всеми орнитологами [Онно, 1975]. Данный метод применялся и нами при определении гнездовых параметров птиц в дельте р. Селенги [Шинкаренко, 1983; Мельников, 2006; 2010в; 2011а; 2014].

Расчет основных показателей успешности размножения птиц проводился с использованием метода Н. Mayfield's [Mayfield, 1961; 1975] в модификации В. А. Паевского [1985]. При небольших интервалах между посещениями гнезд (2-4 дня) он дает хорошие результаты и в настоящее время, несмотря на некоторые методические погрешности [Shaffer, 2004], широко используется для изучения экологии птиц. Анализ собранных материалов проведен с использованием стандартных статистических методов [Закс, 1976].

\section{Результаты}

Многолетние исследования показывают, что основным лимитирующим фактором в дельте Селенги является колебание уровня воды (табл. 2), что подтверждается и наблюдениями других авторов [Мельников, 1977; 1982; 2007а; Иметхенов, 1994; Фефелов и др., 1995; Подковыров, 1997]. Однако его влияние на разные виды птиц неодинаково. Незначительная гибель гнезд от колебаний уровня воды отмечена у видов, гнездящихся преимущественно на деревьях (серая цапля) [Мельников, 2006; 2011a; Мельников и др., 2009]. Только в годы с низкими уровнями воды этот вид занимает вахтовые сплавины, где и отмечалось подтопление кладок - 0,8 \% яиц. При этом надо иметь в виду, что подобная ситуация наблюдалось в конце 11-летнего климатического цикла, когда колебания уровня воды были уже небольшими, по сравнению с началом цикла этого уровня. Низкий отход яиц характерен также для птиц, устраивающих крупные и массивные плавающие гнезда (лысуха) в среднем 5,3 \% отложенных яиц [Мельников и др., 1983; Мельников, 2011a; 2012]. Однако небольшие гнезда белощекой крачки, расположенные по окраинам крупных плесов и построенные из фрагментов стеблей камыша, тростника, а также листьев 
плавающих растений, часто разрушаются волнами и гибнут - $42,1 \%$ от общего количества отложенных яиц [Мельников, 2006б, 2011а; 2012а] (табл. 2).

Незначительная гибель гнезд от подтопления отмечена у видов, гнездящихся на высоких островах или на достаточном удалении от уреза воды (монгольская, сизая чайки и чеграва) - от 2,3 до 6,5 \% отложенных яиц (табл. 2). Птицы, занимающие более высокие участки дельты (высокие прирусловые валы, межозерные калтусы, внутрикалтусные озера, песчаные косы проток и плоские острова на кромке дельты, возвышающиеся над уровнем воды до 10-25 см), в меньшей степени страдают от данного фактора: кряква, красноголовая чернеть и речная крачка - от 9,3 до 11,1\% отложенных яиц (табл. 2). Максимальная гибель гнезд от затопления наблюдается у видов, часто занимающих небольшие сплавины и подтопленные травяные острова на крупных озерных плесах, окраины больших внутрикалтусных озер или устраивающих гнезда по урезу воды: белокрылая крачка, шилохвость, широконоска, чирок-трескунок, хохлатая чернеть, малая и озерная чайки. В таких случаях на гибель гнезд огромное влияние оказывают сильные ветры, вызывающие нагон воды с наветренной стороны озер (сгонно-нагонные явления) - отход составляет от 14,1 до 26,3 \% яиц (табл. 2) [Мельников, 1977; 1982; 2006a; 2006б; 2007a; 2009; 2011a; 2012a].

Таблииа 2

Влияние лимитирующих факторов на успешность насиживания кладок околоводными и водоплавающими птицами в дельте р. Селенги (оз. Байкал) в 1972-1985 гг. (по Мельников, 2010в, с дополнениями)

\begin{tabular}{|c|c|c|c|c|c|c|c|}
\hline \multirow[b]{2}{*}{ Вид } & \multirow[b]{2}{*}{$\begin{array}{c}\text { Общее } \\
\text { кол-во } \\
\text { яиц }\end{array}$} & \multicolumn{6}{|c|}{ Причины отхода, в \% } \\
\hline & & $\begin{array}{c}\text { Колеба- } \\
\text { ния уров- } \\
\text { ня воды }\end{array}$ & $\begin{array}{c}\text { Хищни- } \\
\text { чество } \\
\text { птиц }\end{array}$ & $\begin{array}{l}\text { Хищни- } \\
\text { чество } \\
\text { млекопи- } \\
\text { тающих }\end{array}$ & $\begin{array}{c}\text { Ветро- } \\
\text { вая эро- } \\
\text { зия }\end{array}$ & $\begin{array}{c}\text { Антропо- } \\
\text { генное } \\
\text { воз- } \\
\text { действие }\end{array}$ & $\begin{array}{c}\text { Эмбрио- } \\
\text { нальная } \\
\text { смерт- } \\
\text { ность }\end{array}$ \\
\hline 1 & 2 & 3 & 4 & 5 & 6 & 7 & 8 \\
\hline \multicolumn{8}{|c|}{ Не колониальные виды } \\
\hline Лысуха & 757 & $5,3 \pm 0,8$ & $29,6 \pm 1,7$ & - & - & - & $1,3 \pm 0,4$ \\
\hline $\begin{array}{l}\text { Азиатский } \\
\text { бекасовидный } \\
\text { веретенник }\end{array}$ & 974 & $20,9 \pm 1,3$ & $14,7 \pm 1,1$ & - & - & $2,0 \pm 0,4$ & $3,1 \pm 0,6$ \\
\hline Кряква & 2366 & $11,0 \pm 0,5$ & $16,0 \pm 0,6$ & - & - & $18,2 \pm 0,8$ & $3,3 \pm 0,5$ \\
\hline Шилохвость & 1685 & $15,0 \pm 0,6$ & $21,2 \pm 0,5$ & - & - & $12,5 \pm 0,6$ & $2,7 \pm 0,5$ \\
\hline Чирок-трескунок & 520 & $22,9 \pm 0,4$ & $28,3 \pm 0,4$ & - & - & $20,0 \pm 0,8$ & $4,6 \pm 0,5$ \\
\hline Широконоска & 936 & $14,1 \pm 0,3$ & $16,5 \pm 0,4$ & - & - & $13,3 \pm 0,5$ & $3,6 \pm 0,6$ \\
\hline $\begin{array}{l}\text { Красноголовая } \\
\text { чернеть }\end{array}$ & 1988 & $9,3 \pm 0,3$ & $21,0 \pm 0,2$ & - & - & $6,9 \pm 0,6$ & $3,7 \pm 0,7$ \\
\hline Хохлатая чернеть & 1157 & $17,4 \pm 0,4$ & $29,3 \pm 0,5$ & - & - & $2,2 \pm 0,9$ & $3,9 \pm 0,8$ \\
\hline \multicolumn{8}{|c|}{ Колониальные виды } \\
\hline Серая цапля & 5131 & $0,8 \pm 0,1$ & $21,4 \pm 0,6$ & - & - & $8,0 \pm 0,4$ & $7,5 \pm 0,4$ \\
\hline Малая чайка & 5012 & $19,2 \pm 0,6$ & $8,2 \pm 0,4$ & - & - & - & $10,3 \pm 0,4$ \\
\hline
\end{tabular}


Ю. И. Мельников. Лимитирующие факторы и успешность размножения околоводных и водоплавающих птиц в условиях горно-пойменного водного режима в дельте...

\begin{tabular}{|l|l|l|l|l|l|l|l|}
\hline Озерная чайка & 6485 & $25,0 \pm 0,5$ & $6,4 \pm 0,3$ & - & - & - & $5,3 \pm 0,3$ \\
\hline Монгольская чайка & 3647 & $4,9 \pm 0,4$ & $18,6 \pm 0,6$ & - & - & - & $7,4 \pm 0,4$ \\
\hline Сизая чайка & 3323 & $6,5 \pm 0,4$ & $41,3 \pm 0,9$ & - & - & $5,2 \pm 0,4$ & $8,5 \pm 0,5$ \\
\hline Белокрылая крачка & 13672 & $26,3 \pm 0,4$ & $32,1 \pm 0,4$ & - & - & $2,6 \pm 0,1$ & $6,9 \pm 0,2$ \\
\hline Белощекая крачка & 1009 & $42,1 \pm 1,6$ & $6,6 \pm 0,8$ & - & - & - & $10,4 \pm 0,7$ \\
\hline Речная крачка & 1114 & $11,1 \pm 0,9$ & $5,8 \pm 0,7$ & $1,1 \pm 0,3$ & - & $4,1 \pm 0,6$ & $7,7 \pm 0,8$ \\
\hline Чеграва & 3114 & $2,3 \pm 0,3$ & $2,8 \pm 0,3$ & - & $17,7 \pm 0,7$ & - & $10,5 \pm 0,6$ \\
\hline
\end{tabular}

Необходимо отметить очень большое значение структурной сложности микрои мезорельефа дельты р. Селенги, позволяющих выделить две группы стаций: низкопойменные и высокопойменные водоемы [Мельников, 2007б; 2011б]. Низкопойменные водоемы постоянно находятся под влиянием нестабильного гидрологического режима и отличаются высокой гибелью гнезд. Высокопойменные водоемы испытывают его влияние в годы сильных подъемов уровня воды, когда затапливаются высокие острова нижней дельты и вода выходит на надпойменные террасы. В таких случаях большое количество гнезд гибнет у всех видов. Величина средней многолетней гибели яиц прибрежных птиц полностью определяется частотой повторения сезонов с сильными паводками в середине лета. Перепад уровня воды между началом гнездового сезона и основным периодом насиживания кладок может достигать 109 см.

Другой особенностью высокопойменных водоемов является повышенная гибель гнезд на заболоченных лугах в результате воздействия затяжных (2-4 дня) и ливневых (за сутки выпадает месячная и более сумма осадков) дождей. Для пойменных лугов характерен высокий уровень стояния грунтовых вод. В периоды сильных дождей и ливней наблюдается их временное подтопление и по ложбинам стока вода поступает на участки с более низкими гипсометрическими уровнями (небольшие понижения среди лугов, лужи и временные озерки) [Мельников, 2007б; 2009; 2011а; 2011б; 2012а; 2012б]. На них, из-за небольшой площади, кратковременно, но сильно повышается уровень воды (от 2,0-3,0 до 10,0-15,0 см).

В дальнейшем, по мере накопления воды, идет интенсивный сток осадков в ближайшие озера или реки. Поскольку площадь озер, а, следовательно, и общая площадь растекания воды достаточно велики (площадь водоемов от 0,5 га и выше), уровень воды здесь поднимается только на 1,0-2,0 см. Обычно уже в течение суток скат воды заканчивается. Однако для птиц такие кратковременные подъемы уровня воды могут иметь большое значение, так как эмбрионы затопленных яиц гибнут от переохлаждения через 1,5-2,0 часа. От значительной и катастрофической гибели гнезд в такой ситуации спасает только хорошо развитая адаптация птиц к быстрой их надстройке по мере подъема уровня воды [Мельников, 2011а; 2012a; 2012б].

Важным лимитирующим фактором является и разорение гнезд факультативными хищниками, отличающимися высокой численностью. Мелкие виды птиц (азиатский бекасовидный веретенник, чирок-трескунок, белокрылая и белощекая крачки) с высокой гибелью гнезд от затопления в еще большей степени страдают от хищничества крупных чаек (табл. 2). Более крупные виды, особенно гнездящиеся большими колониями (малая и озерная чайки), страдают от данного фактора в меньшей степени - гибнет 6,4-8,2\% отложенных яиц. В то же время крупному колониальному 
виду - серой цапле - хищничество черной вороны наносит существенный ущерб, отход составляет 21,4 \% отложенных яиц. Последнее связано с отсутствием у нее эффективных защитных реакций от данного хищника, гнездящегося в колониях жертвы. Большое количество яиц гибнет от хищничества в колониях монгольской и сизой чаек (табл. 2). Основная причина этого - сильно развитое хищничество, вплоть до каннибализма [Мельников, Лысиков, 1983; Мельников, 2006а; 2008; 2009в; 2010б]. Чайки этих видов, в случае территориальных конфликтов или отсутствия птиц на соседних гнездах, поедают в них яйца, а нередко и пуховых птенцов.

Разоряют гнезда и отлавливают птенцов преимущественно факультативные хищники (монгольская и сизая чайки, черная ворона и срока). Специализированные пернатые хищники - восточный болотный лунь Circus aeruginosus spilonotus и орлан-белохвост Haliaeetus albicilla - наносят птицам незначительный ущерб. В наибольшей степени страдают более мелкие виды неколониальных птиц (табл. 2). Мелкие колониальные виды успешно отражают атаки хищников, не стремящихся к разорению гнезд данной жертвы - речная крачка 5,8 \% яиц. При целенаправленном преследовании ими массовых мелких видов птиц (белокрылая крачка) гибель яиц может достигать большой величины - 32,1\%.

Хищничество млекопитающих, несмотря на довольно высокую численность в дельте Селенги лисицы обыкновенной Vulpes vulpes, носит случайный характер. Оно связано с изъятием яиц в отдельных доступных с берега колониях речной крачки колонком Mustela sibirica - 1,1 \%. По нашим наблюдениям, крупные хищные млекопитающие (лисица обыкновенная, барсук азиатский Meles leucurus) предпочитают отлавливать на гнездах насиживающих самок (преимущественно уток) или нелетный молодняк более крупных птиц.

Еще более специфичным лимитирующим фактором является ветровая эрозия почвы. Влияние данного фактора зафиксировано нами только в колониях чегравы, гнездящейся по наиболее высоким гребням песчаных островов, отделяющих мелководья дельты от глубоководной части оз. Байкал. При отсутствии птиц на гнезде более 40 мин, что часто наблюдается на первых этапах формирования кладки, она засыпается сухим песком, перемещаемым даже слабым ветром. Этому, несомненно, способствует и отсутствие гнездовой выстилки - гнездо представляет лунку в песке. Возвратившиеся на гнездо птицы, находят кладку и освобождают ее от песка (визуальные наблюдения). Тем не менее достаточно большое количество гнезд теряется птицами, а общая гибель яиц от этого фактора достигает в среднем 17,7 \% (табл. 2). В таких же условиях речная крачка гнездится на более низких участках со слежавшимся песком, который не перемещается ветром.

Из антропогенных факторов явное влияние на птиц оказывают выжигание растительности, выпас скота, сенокошение и беспривязное содержание пастушеских собак. Выжигание растительной ветоши в весенний период характерно для высоких и более сухих участков дельты р. Селенги, используемых в летний период под сенокосы. Плотность населения птиц здесь невелика, но может увеличиваться в годы с высоким весенним уровнем воды. В годы с ранним началом размножения выжигание растительности может приводить к гибели некоторой доли ранних кладок [Мельников, 2006]. Сенокошение оказывает очень незначительное влияние 
Ю. И. Мельников. Лимитирующие факторы и успешность размножения околоводных и водоплавающих птиц в условиях горно-пойменного водного режима в дельте...

на гнездящихся птиц, поскольку основная их часть к этому времени уже заканчивает насиживание кладок.

На небольших участках, преимущественно высоких хорошо обдуваемых местах у проток и озер, скот собирается в жаркие дни, спасаясь от кровососущих насекомых. Здесь от вытаптывания гибнут практически все гнезда. Они часто затаптываются и в местах перегона скота из одного участка дельты в другой - в таких случаях он перемещается плотной «лавиной». В обычных условиях выпаса крупный рогатый скот и лошади обходят гнезда, и мы нередко наблюдали, как они объедали траву по их краю, а самки птиц спокойно насиживали кладку и даже отгоняли их от гнезда (насиживающие утки вытягивали шею и шипели в сторону нарушителей спокойствия).

В отдельных случаях кладки птиц разоряли собаки, сопровождающие пастухов. Рекреационная деятельность на нижних участках дельты Селенги (фототуризм) развита слабо, а рыболовы обычно используют участки с низкой численностью птиц (преимущественно воробьиных). Места массового отдыха населения расположены на островах высокой части дельты, где плотность населения птиц относительно невелика. В большей степени страдают виды, оставляющие кладки после вспугивания с гнезда (преимущественно на начальных стадиях насиживания) - кряква, шилохвость, чирок-трескунок и широконоска [Мельников, 2006]. Суммарная гибель яиц от данных факторов у этих видов составляла в среднем 12,5-20,0 \%. У остальных видов она, как правило, не превышала 2,0-8,0% (табл. 2).

Эмбриональная смертность довольно сильно отличалась у разных видов (табл. 2). В основном это связано с частотой затопления кладок, так как в таких случаях некоторая часть яиц практически всегда гибнет от переохлаждения. Отмечались случаи гибели эмбрионов на разных стадиях развития (генетические причины) и увод выводка из гнезда до вылупления всех птенцов (неблагоприятные погодные условия). В таких случаях гибнут последние яйца кладки (нередко уже проклюнутые). Общая гибель по этим причинам составляет у разных видов от 1,3 до 10,5 \% отложенных яиц (табл. 2).

Гибель яиц существенно меняется у разных видов, но отличия между колониальными и неколониальными видами относительно невелики (рис. 1). В большем количестве гибнут кладки у неколониальных видов птиц. Определенно, смертность в этот период в большей степени обусловлена местом гнездования. Расположение гнезд на быстро подтапливаемых участках ведет к увеличению гибели яиц как от затопления гнезд, так и от хищничества крупных чаек, а в ряде случаев и от вытаптывания скотом (речные утки). В целом гибель яиц у чайковых птиц среднего и крупного размера существенно ниже, чем у более мелких видов. Исключением является сизая чайка, у которой в результате каннибализма гибнет большое количество яиц (рис. 1). Эта же закономерность прослеживается и среди неколониальных видов птиц (табл. 1).

После вылупления птенцов распределение птиц заметно меняется. Выводки даже у многих колониальных видов, концентрируются на участках с более благоприятными кормовыми и защитными условиями. Это наиболее характерно для болотных крачек, осваивающих озерные плесы и перемещающихся с выводками по водоему, т. е. колония как пространственная единица у данных видов к этому времени ча- 
сто распадается. Крупные чайки, занимающие более стабильные местообитания, сохраняют привязанность к определенному участку колонии до подъема птенцов «на крыло». В связи с заметным улучшением защитных условий, за счет хорошего развития травяного покрова к моменту массового вылупления птенцов смертность их, по сравнению с гибелью яиц в период насиживания кладок, явно снижается.
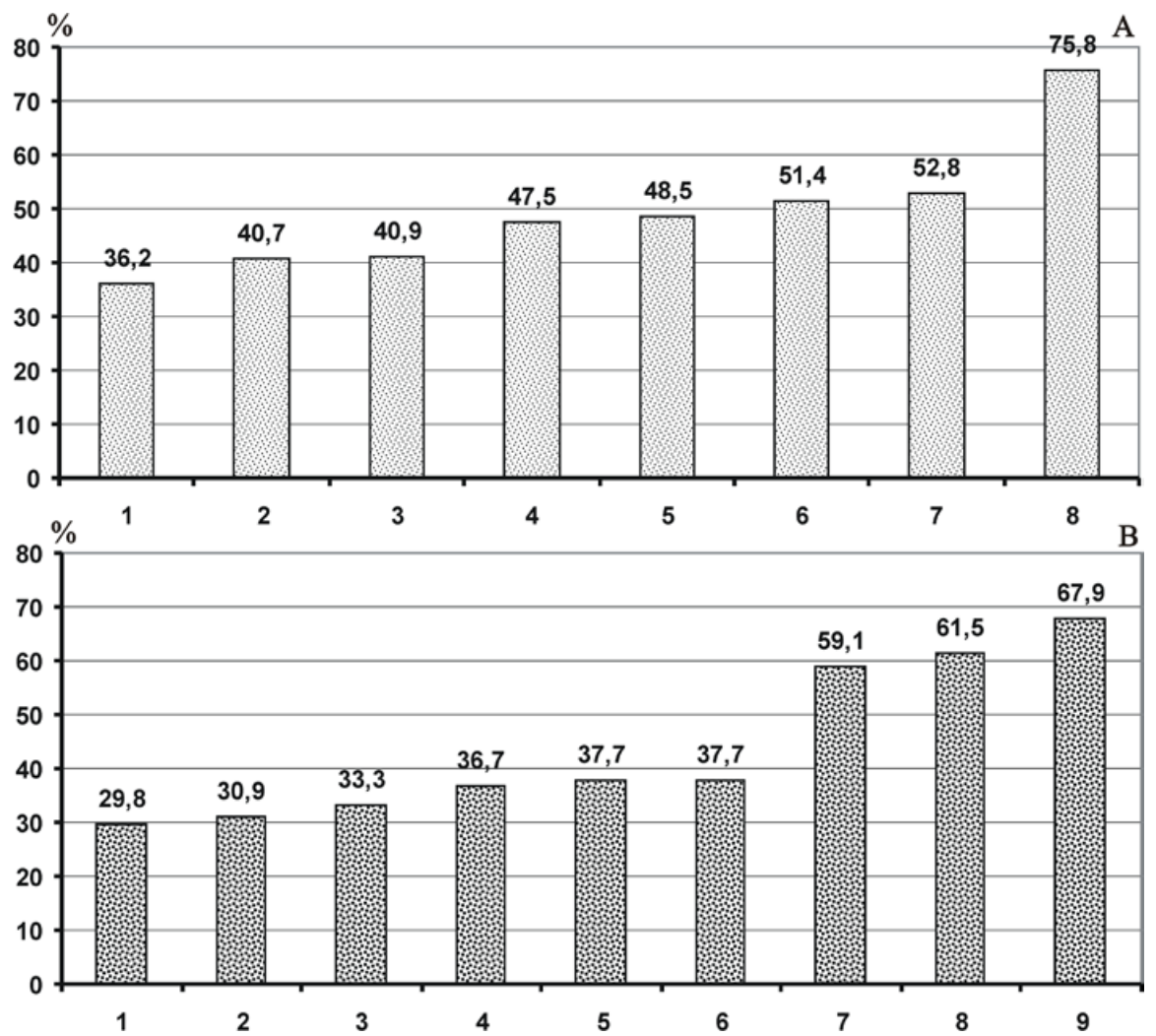

Puc. 1. Общая гибель яиц в период насиживания у колониальных и неколониальных видов прибрежных птиц

A-неколониальные виды: 1 -льсуха; 2 - азиатский бекасовидный веретенник; 3 - красноголовая чернеть; 4 - широконоска; 5 - кряква; 6 - шилохвость; 7 - хохлатая чернеть; 8 - чирок-трескунок.

B - колониальные виды: 1 - речная крачка; 2 - монгольская чайка; 3 - чеграва; 4 - озерная чайка; 5 - серая цุапля; 6 - малая чайка; 7 - белощекая крачка; 8 - сизая чайка; 9 - белокрылая крачка.

Однако у некоторых видов смертность птенцов может сохраняться на достаточно высоком уровне. Наибольшие потери несут неколониальные виды, прежде всего водоплавающие птицы, часто переводящие птенцов через большие участки открытой воды. Здесь они подвергаются активным атакам крупных чаек. В благоприятной ситуации, когда нападает несколько птиц, чайки могут успешно отлавливать весь выводок. Обычно же они успевают изъять из него трех-четырех утят [Мельников, 1979; 1992; 2010б; Мельников, Лысиков, 1983; Мельников и др., 1984; Мельников, Мельникова, 1992]. 
Ю. И. Мельников. Лимитирующие факторы и успешность размножения околоводных и водоплавающих птиц в условиях горно-пойменного водного режима в дельте...

Колониальные виды птиц, прежде всего монгольская и сизая чайки, теряют птенцов во время кратковременных голоданий, часто наблюдающихся во время штормовых ветров, продолжающихся 3-4 дня [Мельников, 1987]. В таких случаях за счет достаточно сильно развитого каннибализма отдельных особей их трупы очень быстро используются в пищу [Мельников, 1992; 2010б; Мельников, Мельникова, 1992]. В меньшей степени это характерно для других видов чайковых птиц, не имеющих возможности охотиться и кормить птенцов в такую погоду. Однако влияние хищничества в данный период определенно снижается, хотя болотный лунь и орлан-белохвост часто выкармливают птенцов молодняком прибрежных птиц.

Птенцов всех видов птиц часто отлавливают крупные щуки (от 7-8 кг и выше), подкарауливающие выводки у кромки береговой растительности [Мельников, 2009в; 2010в]. На отдельных участках дельты Селенги с обширными прогреваемыми мелководьями, на которых концентрируются птицы с выводками и часто охотятся крупные щуки, локальный отход может быть достаточно ощутимым (не менее $25,0-30,0 \%$ птенцов, держащихся в этом месте). Однако в целом гибель молодых птиц от данного фактора невысока и вряд ли достигает 0,5 \% общего количества вылупившихся птенцов.

В период выращивания птенцов смертность явно выше у видов с более высокой успешностью размножения - от 11,5 до 30,4 \% количества вылупившихся птенцов (рис. 2). Это явно связано с тем, что в это время они являются наиболее доступной и массовой жертвой, на что уже указывали некоторые авторы [Nisbet, 1975]. Птенцы малой и озерной чаек сильно страдали от территориальных конфликтов насиживающих птиц. Дело в том, что наиболее активные птенцы через три-четыре дня после вылупления покидали гнездо и начинали бродить в его окрестностях. Они обычно подвергались нападениям насиживающих птиц из соседних пар. В результате сильных ударов часть из них погибала, а другие возвращались в гнездо со скальпированной головой [Гилевич, 1977; Мельников, 2006]. Следы ударов сохранялись до подъема молодых птиц «на крыло». Такое поведение взрослых птиц являлось сбросом отрицательных мотиваций в переуплотненных колониях. В меньшей степени данная тенденция отмечалась в колониях других видов чайковых птиц.

Однако имеются и исключения, связанные с более высоким уровнем размножения в крупных и плотных группах птиц и, как правило, обусловленные особенностями гнездовых биотопов и защитным поведением птиц, определяемыми морфобиологическим обликом вида. Минимальная гибель птенцов характерна для лысухи - 7,7 \%. Она отличается агрессивной защитой выводков, а размеры и острый крепкий клюв позволяют ей отражать атаки даже крупных хищников (монгольская и сизая чайки) [Мельников и др., 1987]. Другой вид - чеграва (смертность птенцов 12,8 \%) гнездится в местообитаниях с небольшим количеством потенциальных хищников (песчаные отмели по кромке дельты Селенги) (рис. 2). Кроме того, она отличается крупными размерами и очень агрессивным поведением при защите птенцов, которые после вылупления собираются в ясли, охраняемые многими птицами в момент нападений хищничающих птиц, находящихся в колонии. 

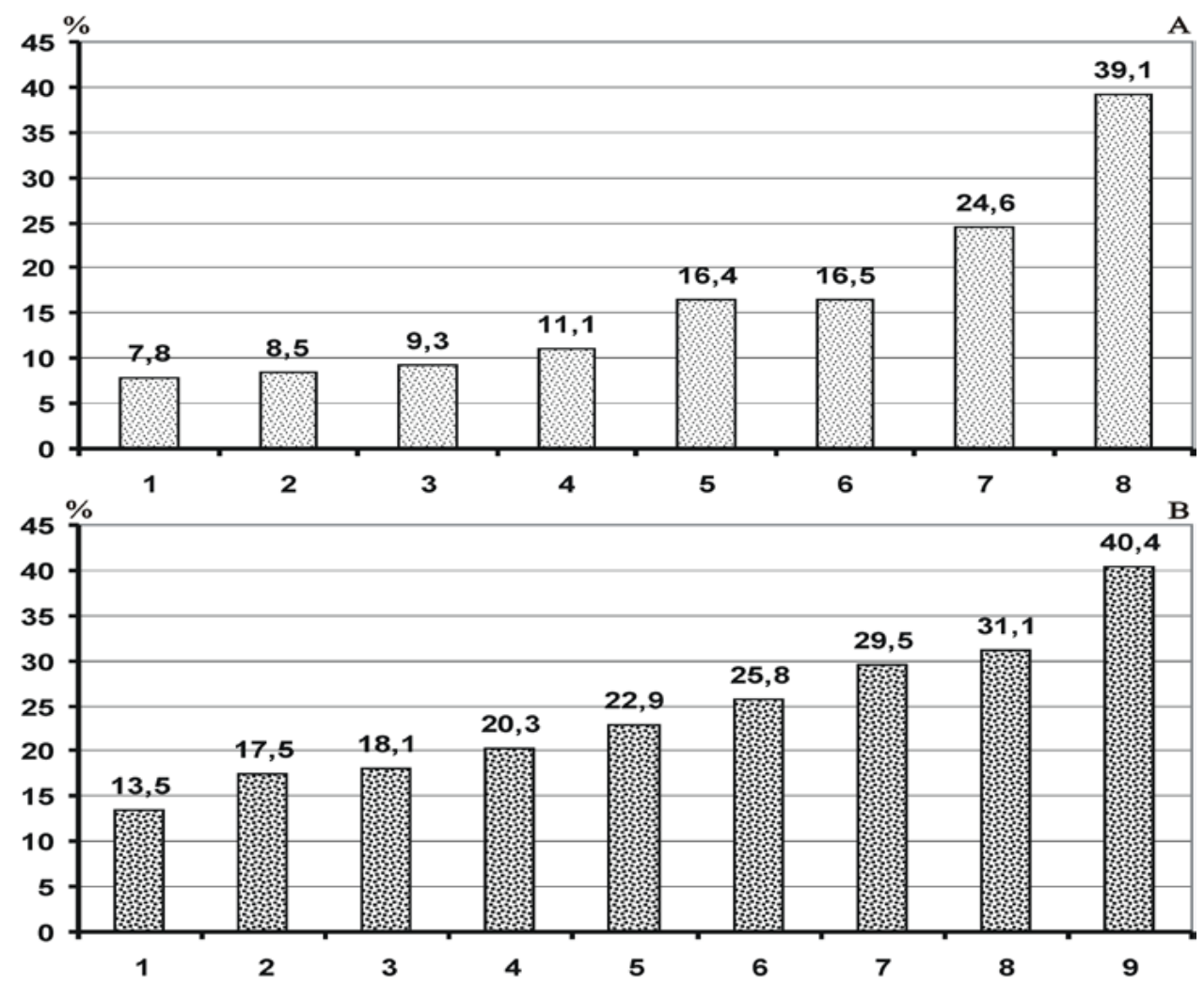

Puc. 2. Общая гибель птенцов в период вождения выводков у колониальных и неколониальных видов прибрежных птиц

A-неколониальные виды: 1 - льсуха; 2 - кряква; 3 - шилохвость; 4 - чирок-трескунок; 5 - широконоска; 6-красноголовая чернеть;

7 - хохлатая чернеть; 8 - азиатский бекасовидный веретенник.

В - колониальные виды: 1 - чеграва; 2 - малая чайка; 3 - серая цуапля;

4 - озерная чайка; 5 - монгольская чайка; 6-белощекая крачка;

7 - белокрылая крачка; 8-речная крачка; 9 - сизая чайка.

Высокая смертность провоцируется и поведением птенцов, часто «путешествующих» вокруг гнезда, что вызывает агрессивное поведение соседних пар, особенно в смешанных колониях нескольких видов. В этом отношении резко выделяется речная крачка, отличающаяся очень высокой агрессивностью при совместном гнездовании птиц. Птенцы, ушедшие из гнезд, особенно уже заметно подросшие, а в некоторых случаях достигшие размеров взрослой птицы, но еще не летающие, часто пытаются выпрашивать корм у взрослых птиц любого вида. Очевидно, у речной крачки такое поведение провоцируется видом небольшой рыбки в клюве и специальными криками птицы, подзывающей к себе своих птенцов. Чужие птенцы, кинувшиеся к ней, часто другого вида, получают очень сильные удары, иногда заканчивающиеся их гибелью. Такое поведение провоцируется и подлетом к гнезду птицы, насиживающей кладку или обогревающей пуховых птенцов, партнера с добычей. В таких случаях птенцов бьют обе птицы. Нам неоднократно приходилось находить в смешанных колониях, особенно в которых один из видов приступил к гнездованию значительно 
Ю. И. Мельников. Лимитирующие факторы и успешность размножения околоводных и водоплавающих птиц в условиях горно-пойменного водного режима в дельте...

раньше, у гнезд насиживающих птиц по 3-4 мертвых птенца, иногда уже достигших размеров взрослой птицы. Наибольшая гибель птенцов в таких случаях характерна для смешанных колоний белокрылой и речной крачек, отличающихся в этот период очень высокой агрессивностью.

Высокий отход птенцов отмечен у сизой чайки (37,5\%) (рис. 2), и единственная причина этого - сильно развитый каннибализм. У монгольской чайки, которая также демонстрирует склонность к его проявлению, смертность птенцов значительно ниже - 21,3\%. Практически такой же уровень смертности молодых птиц отмечен среди болотных крачек (23,4-35,8\%) (рис. 2) [Мельников, Мельникова, 1992; Мельников, 2010б]. Однако его основная причина - специфические местообитания (окраины обсыхающих озер и болота). В начале формирования колонии они занимают совершенно открытые хорошо инсолированные участки с грязевыми отмелями. Однако к моменту вылупления птенцов они покрываются растительностью с высокой долей хвоща топяного Equisetum fluviatile, который в дельте Селенги имеет очень благоприятные условия для развития и иногда достигает роста человека. Микроклимат таких местообитаний неблагоприятен для пуховых птенцов, и большое их количество гибнет от переохлаждения при долгом отсутствии родителей, особенно в ненастную погоду.

Разумеется, невозможно точно определить силу влияния каждого из этих факторов в период вождения выводков. Однако специальные эксперименты с мечением пуховых птенцов и просмотром погадок крупных чаек в колониях подтвердили наши выводы о значительном их влиянии на смертность птенцов околоводных и водоплавающих птиц [Мельников, 1992; 2010б; 2012б; Мельников, Мельникова, 1992]. В целом в данный период оценивалась только общая смертность по разности между количеством вылупившихся птенцов и количеством молодых птиц, поднявшихся «на крыло». Кроме того, на основе постоянных натурных наблюдений выяснялись факторы смертности, характерные для отдельных видов или групп видов птиц.

Необходимо отметить, что гибель яиц и птенцов могла быть значительно выше, но все изученные нами виды имели комплекс специальных защитных адаптаций, позволяющих им снижать уровень смертности яиц и птенцов. Для неколониальных видов птиц характерен комплекс отвлекающих наземных демонстраций, позволяющий отвести хищника от кладки или птенцов (в общем виде - отвод от гнезда и птенцов, прикидываясь больной или раненной птицей). Для мелких видов отражение атак пернатых хищников часто сводится к моббингу, когда несколько птиц, формирующих агрессивную и беспокоящуюся стаю, окрикивают его, обрызгивают пометом и явно мешают сосредоточиться на поиске гнезд и птенцов. Такое поведение в ряде случаев позволяет спасти некоторое количество кладок, даже при достаточно плотном гнездовании птиц. Для колониальных птиц характерны только агрессивные атаки на хищника (нет наземных отвлекающих демонстраций), начиная с моббинга, в крайнем выражении завершающиеся агрессивными пикирующими налетами и его ударом клювом, крылом или лапой. Практически все виды птиц имеют подобные защитные реакции, иногда отличающиеся значительной сложностью. Они описаны в специальной литературе, хотя этот вопрос требует дальнейшего более детального и специального изучения [Флинт, 1977; Мельников, 1982; 1987; 1997; 2006а; 2008а; 
2008б; 2010а; 2017a; 2017б; Тихонов, Фокин, 1982; Мельников, Лысиков, 1983; Мельников и др., 1987; Armstrong, 1947; Simmons, 1955].

До сих пор остается открытым вопрос, насколько выше репродуктивный успех у колониальных птиц по сравнению с неколониальными видами. У колониальных птиц он несколько выше, и это в большинстве случаев очевидно. Расчет данного показателя на материалах, полученных в разных регионах, не может быть корректным. Такие регионы обычно хорошо различаются по составу и силе воздействия лимитирующих факторов. Вполне очевидно, что надо сравнивать результаты исследований, полученных в одном и том же регионе и в одни и те же сроки. Только в таком случае подобные сравнения будут корректными.
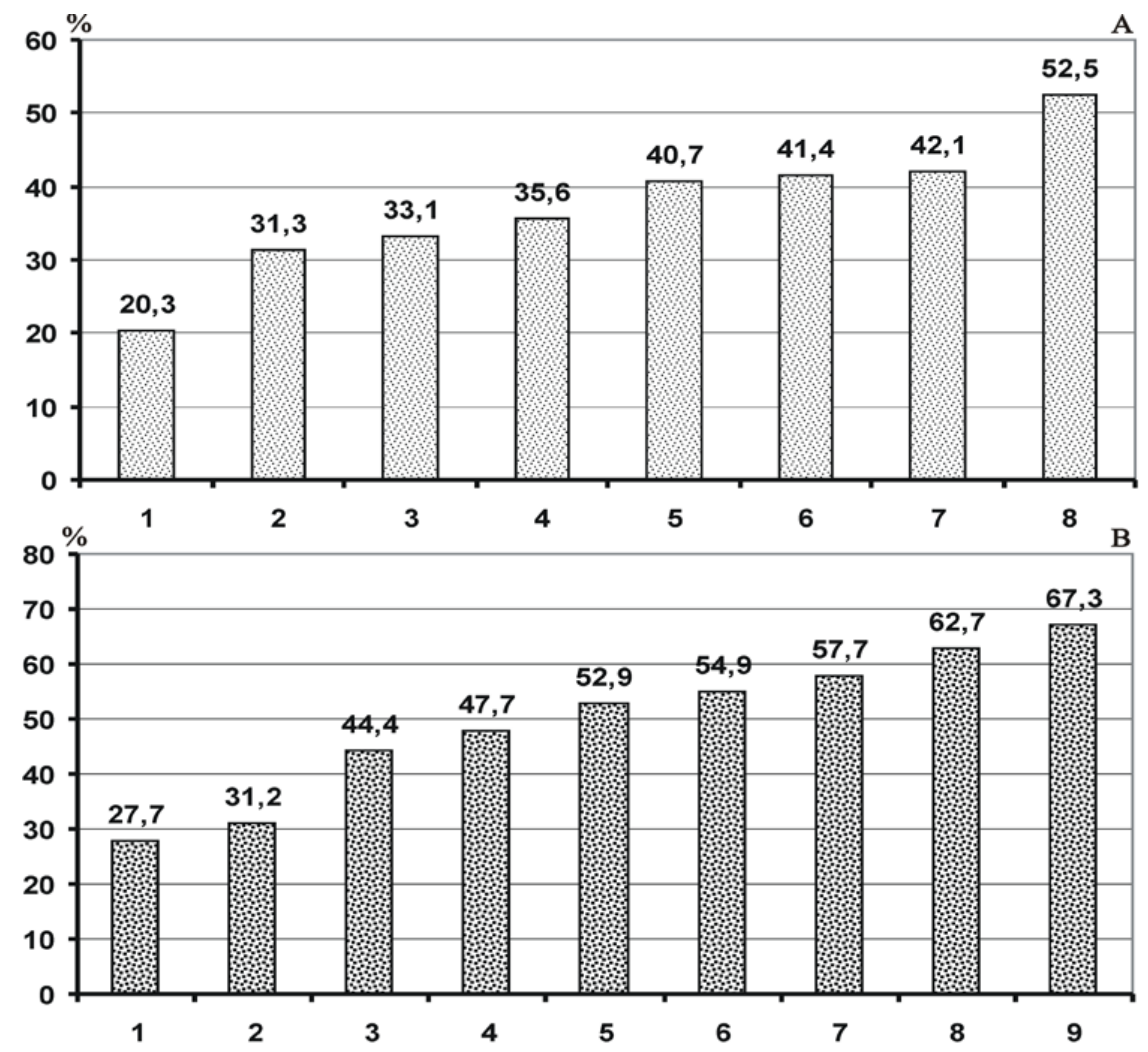

Pис. 3. Общая успешность размножения колониальных и неколониальных видов прибрежных птиц

A-не колониальные виды: 1 - чирок-трескунок, 2 - азиатский бекасовидный веретенник, 3 - хохлатая чернеть, 4 - кряква, 5 - красноголовая чернеть,

6 - иилохвость, 7 - широконоска, 8 -лысуха.

B - колониальные виды:: 1 - сизая чайка, 2 - белокрылая крачка, 3 - белощекая крачка, 4 - речная крачка, 5-малая чайка, 6-монгольская чайка, 7 - серая цุапля, 8 - озерная чайка, 9 - чеграва.

В нашем случае, как показывает многолетняя практика работ, результаты исследований, полученные на основе сравнений очень больших объемов выборок гнезд разных видов, всегда будут достоверными. Для того чтобы более точно рассчитать 
Ю. И. Мельников. Лимитирующие факторы и успешность размножения околоводных и водоплавающих птиц в условиях горно-пойменного водного режима в дельте...

средние данные по успешности размножения разных групп видов, нами использовался средневзвешенный показатель общей успешности размножения колониальных и неколониальных видов птиц. На нашем материале колониальные виды птиц в среднем имели более высокую общую успешность размножения - 46,9 \%, в то время как неколониальные виды - только 37,9 \%. Таким образом, успешность размножения колониальных видов птиц в среднем выше на 9,0 \% (рис. 3).

Несомненно, бо́льшая успешность размножения колониальных видов птиц обусловлена меньшей гибелью кладок в период насиживания, поскольку гибель птенцов от разных причин у них явно выше (рис. 1, 2, 3). Защитные реакции достаточно хорошо развиты в обеих изученных группах птиц. Однако явно видно, что для неколониальных видов птиц характерны наземные отвлекающие демонстрации, направленные на защиту гнезд и птенцов именно от наземных хищников. От пернатых хищников их спасает хорошая маскировка гнезд и защитная окраска насиживающих самок, а также дефекация на гнездо жидким и сильно пахнущим пометом наряду с определенными элементами агрессивных реакций, поскольку даже моббинг - агрессивная реакция.

Напротив, у колониальных видов места гнездовий хорошо заметны, и их поиск не вызывает значительных затруднений у хищников. Однако попасть в колонию и разорить гнездо или поймать насиживающую птицу часто бывает весьма затруднительно. Комплекс защитных реакций данной группы птиц состоит из агрессивных атак большого количества птиц, защищающих колонию, и явно сформировался для защиты не от наземных, а от пернатых хищников. Хотя факты активной дефекации в колонии указывают, что эта реакции явно служит для отпугивания наземных хищников. У факультативно колониальных видов чайковых птиц иногда отмечаются и попытки использования сильно редуцированных отвлекающих демонстраций [Мельников, 1987]. Однако и против наземных хищников колониальные виды используют преимущественно именно агрессивные воздушные атаки.

В то же время имеется большое количество описаний достаточно легкого проникновения хищников в колонию [Зубакин, 1983; Панов, 1983; Харитонов, 1983; Черничко, 1983; Глушенков, 2012]. Этот факт указывает на формирование у них определенных типов поведения, позволяющих проникать в колонию, разорять кладки и отлавливать птенцов, а иногда и взрослых птиц. Насколько они могут быть разнообразными, указывают наши наблюдения за хищничающими монгольскими и сизыми чайками. Мелкие виды чаек в дельте р. Селенги реагируют на них как на хищников. Тем не менее они достаточно легко проникают в их колонии. Монгольские чайки, несмотря на непрерывные атаки птиц, в паре легко скидывают с гнезда насиживающую озерную чайку и разоряют ее кладку, поедая яйца. Более мелкая сизая чайка использует другой подход для вспугивания насиживающей птицы с гнезда. Она поднимается вверх и пикирует на гнездо с громким криком, разворачивая крылья и снова поднимаясь вверх в 1,5-2,0 м от насиживающей птицы. Обычно двух-трех таких атак бывает достаточно для того, чтобы насиживающая птица покинула кладку, предоставляя возможность свободного ее разграбления [Мельников, 1979; 1982; 1987; 1992; 2010б; Мельников, Садков, 1977; Мельников, Лысиков, 1983; Мельников, Мельникова, 1992]. В то же время надо иметь в виду, 
что достаточно легкое проникновение хищников в колонию наблюдается в регионах, где хищничество не является основным лимитирующим фактором и видовой состав хищников, а тем более их численность, весьма ограничен. Хотя даже в таком случае отдельные пары хищников, в дельте р. Селенги восточный болотный лунь и орлан-белохвост, могут специализироваться на добыче птиц в колонии, используя для этого разнообразные методы. Однако в целом гибель яиц и птиц от таких хищников обычна невелика.

\section{Обсуждение}

Многолетние исследования экологии околоводных и водоплавающих птиц Восточной Сибири (1968-2019 гг.) показали, что плотность их населения очень сильно варьирует по разным участкам ареала не только по смежным годам, но и в пределах одного сезона. Даже типичные одиночно гнездящиеся птицы в определенных условиях формируют плотные гнездовые агрегации, не отличающиеся по крайней мере от факультативно колониальных видов птиц [Мельников, 1981в; 1983; 1985; 1991; 1997; 2006а; 2008a; 2008б; 2009а; 2010а; 2010г; Мельников и др., 1983; 1987; 1984]. Причина этого одна - сверхобилие кормовых ресурсов на отдельных участках ареала или района гнездования [Бекман, Мизандронцев, 1971; Мельников, 1985; 1991; 1997; 2006а; 2008a; 2012]. Уже одно это ставит под сомнение выбор в качестве основного признака колонии плотность гнездования [Мельников, 1985; 1997; 2008; 2012].

Важно отметить, что и колониальные виды, даже облигатно колониальные (в нашем случае - чеграва), гнездятся одиночными парами. Необходимо указать, что в дельте p. Селенги отсутствует дефицит мест, пригодных для гнездования птиц. Структурная сложность рельефа очень высока, обеспечивая необходимыми для размножения условиями все их виды [Мельников, 2011б; 2016]. Все же такие случаи не бывают массовыми и могут рассматриваться как исключения из общего правила. Особенно сильно увеличивается количество одиночно гнездящихся пар колониальных видов птиц в годы с очень низким уровнем воды. В это время по периметру дельты Селенги формируются обширные песчаные пляжи, на более высоких участках покрытые растительностью. Однако колонии, особенно крупные, формируются на островах в непосредственной близости от устьев проток, впадающих в соры или на их крутых изгибах, преимущественно в нижнем течении. В этих местах формируются крупные пятна седиментации, содержащие большое количество плохо отсортированного органического материала, переносимого сюда с размываемых верхних участков дельты Селенги [Власова, 1983; Мельников, 1997; 2000; 2006б; 2010г; 2011б; 2012г; 2016 ]. Эти пятна отличаются повышенным содержанием бентоса [Бекман, Мизандронцев, 1971] и привлекают рыбу, а на кормежку и гнездование - большое количество птиц разных видов [Мельников, 2000; 2006б; 2011б; 2016].

Многолетние исследования, анализ собранных данных и литературы показывают, что любая репродуктивная единица, а тем более их скопления должны выполнять несколько функций одновременно: трофическую, репродуктивную и защитную. Это особенно подчеркивается в специальной работе Е. Н. Панова [1983], один из разделов которой посвящен специальному анализу социодемографических структур у птиц. Очевидно, колония должна выполнять все эти функции, что мы и наблюдаем в группе птиц, принадлежность которых к колониальным видам не вызывает 
Ю. И. Мельников. Лимитирующие факторы и успешность размножения околоводных и водоплавающих птиц в условиях горно-пойменного водного режима в дельте...

сомнений (чайковые птицы пресноводных водоемов). Необходимо отметить, что такие функции характерны для всех пар гнездящихся видов, но у колониальных птиц они выполняются всей колонией как структурной единицей вида. Внутри скоплений также начинают работать механизмы саморегуляции, обусловленные высокой плотностью гнездования. Они уже могут рассматриваться, как определенные социодемографические структуры конкретного вида [Мельников, 2000; Waddington, 1942; Wittenberger, Hant, 1985; Brown, Brown, 2001]. Колония отличается от простых скоплений птиц высокой плотностью гнездования, синхронизацией размножения и специфичными агрессивными реакциями на хищников. Все эти признаки присутствуют в ней одновременно [Мельников, 1981в; 1997; 2008].

Совместное гнездование колониальных и неколониальных видов птиц (имеется в виду гнездование в одном районе, отличающемся специфическими условиями обитания) очевидно должно обеспечиваться определенными комплексами адаптаций, присущих обеим группам птиц. Это действительно так. Гнездование в крайне неустойчивых условиях среды, фактически на пределе репродуктивных возможностей видов, обеспечивается комплексом взаимодополняющих адаптаций: достройка гнезд по мере подъема уровня воды, повторное (компенсационное) размножение после гибели кладок, разнообразные защитные реакции от хищников и динамичная пространственная структура [Мельников, 1977; 1981a; 1982; 1987; 2006б; 2007б; 2011а; 2011в; 2011г; 2012a; 2013; 2014a]. Эти адаптации присутствуют как у колониальных, так и неколониальных видов, но динамичная пространственная структура наиболее четко и полно работает у колониальных видов птиц [Мельников, 1981a; 2006б; 1982; 2003a; 2010в]. Несмотря на существенные различия в экологии разных видов околоводных и водоплавающих птиц, для этих адаптаций характерна высокая степень универсальности, обусловленная обитанием птиц в одинаковых условиях среды.

Данные адаптации являются взаимодополняющими, поскольку ни одна из них самостоятельно не может обеспечить необходимый уровень воспроизводства птиц. Работа каждой из них увеличивает в среднем успешность размножения всего на несколько процентов - от 1,0-1,5 до 3,0-5,0 \%. В отдельных случаях их вклад может быть более значительным, до 40,0\%, но такие ситуации достаточно специфичны и встречаются редко [Мельников, 1982; 2006б; 2011в; 2012б; 2014а]. Совместная же их работа в большинстве случаев позволяет поддерживать средний уровень репродукции, характерный для данной местности. Анализ собранных материалов показывает, что колониальные и неколониальные виды птиц, занимающие одни и те же местообитания и испытывающие одинаковую силу воздействия лимитирующих факторов, мало различаются по успешности размножения.

Однако все же такие различия есть. Начиная с самой обычной адаптации - достройка гнезд в высоту по мере подъема уровня воды, они легко прослеживаются у разных видов. Наиболее совершенная и четко выраженная реакция, независимо от систематической принадлежности вида или отнесения его к определенному типу колониальности, свойственна птицам, занимающим наиболее нестабильные местообитания, часто заливаемые водой. Пальму первенства здесь держат малая чайка, все виды болотных крачек и азиатский бекасовидный веретенник [Мельников, 1977; 1982; 2006б; 2006в; 2011г; 2012а]. Несмотря на то, что при очень быстром подъеме 
уровня воды основная часть кладок гибнет у любого вида, все сохранившиеся кладки находятся в достроенных гнездах. Без использования данной адаптации гибель гнезд была бы полной. В данном случае важно, что основная часть видов с наибольшим совершенством подобной реакции относится к колониальным птицам. Небольшое, но преимущество, явно обусловленное тем, что в плотных скоплениях птицы легче решают эту задачу путем подражания более опытным парам [Мельников, 2011; 2012a].

Другая очень важная адаптация - повторное (компенсационное) размножение после гибели первой кладки в одинаковой степени хорошо развита и у неколониальных и у колониальных видов птиц. Это сложная физиологическая адаптация, с помощью которой птицы обеспечивают репродуктивный успех за счет повторного гнездования. Ее реализация - очень сложный феномен эволюции, требующий специального изучения. Различия между разными группами птиц отсутствуют, но у колониальных видов к повторному гнездованию приступает сразу большое количество птиц, что в благоприятных условиях обеспечивает более высокий репродуктивный успех.

Защитные реакции от хищников. В плотных скоплениях неколониальных видов использование отвлекающих демонстраций против наземных хищников лишено смысла. Демонстрирующая реакцию раненой или больной птицы особь ставит под угрозу обнаружения соседние гнезда, которые находятся хищником случайно, при преследовании отводящей птицы. Отражение атак пернатых хищников у таких видов часто невозможно, поскольку их морфологический облик не позволяет использовать удары клювом (он очень слабый или его форма не позволяет нанести болезненный удар). От обнаружения кладки пернатым хищником спасают пассивные адаптации - хорошо укрытое гнездо и криптическая окраска насиживающей птицы. Все эти реакции хорошо работают только при разреженном гнездовании и размножение таких птиц в плотных группах, наблюдающееся в очень благоприятных (сверхобилие кормовых ресурсов) или неблагоприятных (ограниченный по площади гнездовой биотоп) условиях среды, несомненно, снижает их репродуктивный успех.

В свете этих фактов становится понятным, почему истинно колониальные виды утратили отвлекающие демонстрации (как указано нами выше, у них встречаются упрощенные попытки отвода от гнезда) и перешли на агрессивные реакции, нередко завершающиеся ударом противника. Морфологический облик колониальных видов птиц обычно позволяет использовать именно такие реакции. Однако надо отметить, что многолетние наблюдения позволили выявить специфику их использования. Эффективность защиты колоний от нападений хищников, особенно у мелких видов, таких как болотные крачки, часто определяется присутствием среди них очень агрессивных особей. Именно они способны нанести удар хищнику, а остальные птицы не завершают атаки ударом противника. Для них более характерны реакции, близкие к моббингу. Важно и то, что агрессивные воздушные атаки в одинаковой степени действенны, при нападении как наземных, так и пернатых хищников [Мельников, 1979; 1982; 1987; 2006б; 2014a; Мельников, Лысиков, 1983]. Чем больше в колонии агрессивных птиц, тем более высока эффективность ее защиты. Именно эти реакции повышают общую успешность размножения колониальных видов птиц, хотя при направленном нападении группы крупных хищников данные реакции также 
Ю. И. Мельников. Лимитирующие факторы и успешность размножения околоводных и водоплавающих птиц в условиях горно-пойменного водного режима в дельте...

становятся малоэффективными [Мельников, 1987; Мельников, Лысиков, 1983]. Тем не менее в среднем они обеспечивают некоторое повышение успешности размножения у колониальных видов птиц. По нашим наблюдениям, в пределах 1,0-3,5\%.

Из всех рассмотренных нами адаптаций колониальных и неколониальных видов птиц только высокая плотность гнездования приносит отрицательные эффекты. За счет конфликтов между птицами, вызванных повышенной плотностью гнездования и нередко заканчивающихся ударом более слабого противника, в колониях гибнет достаточно большое количество птенцов. Все такие удары являются сбросом отрицательных мотиваций, а не направленным механизмом снижения плотности гнездования. Однако это заметно снижает общую успешность размножения колониальных видов птиц. Тем не менее она все же выше, чем у неколониальных видов, поскольку другие адаптации нивелируют отрицательный эффект высокой плотности гнездования птиц.

Мы рассмотрели адаптации, свойственные обеим группам птиц. Однако у колониальных видов имеется еще одна адаптация, возникшая как ответ на гнездование плотными группами - высокая синхронизация размножения [Мельников, 1981в; 1982; 1985; 1997; 2003б; 2006; 2012в; 2013]. Колониальные виды птиц гнездятся группами с очень сходным ритмом размножения. Нередко колонии, включающие 50-100 пар, приступают к гнездованию за 4-7 дней. В тех случаях, когда птицы в очень благоприятных местах или на ограниченной для устройства гнезд площади формируют сложные колонии, состоящие из нескольких групп (колоний) с синхронным гнездованием, общий период размножения в них может составлять весь гнездовой сезон. Именно в связи с этим синхронность размножения колониальных видов птиц до сих пор слабо изучена. Между тем именно эта адаптация позволяет использовать колониальным видам крайне нестабильные местообитания, сохраняя при этом достаточно высокий уровень размножения [Мельников, 1981a; 1982; 2008; 2013; 2014a; Darling, 1938; Willson, 1974; Emlen, Demong, 1975; Mel'nikov, 1985; 1998].

Для дельты р. Селенги, с высокой доступностью и большим количеством мест, удобных для гнездования колониальных птиц, чрезвычайно характерно размножение небольшими колониями [Мельников, 1988; Mel'nikov, 1985]. Их доля всегда выше, чем более крупных колоний. Вместе с тем необходимо отметить, что истинное их количество в начале сезона размножения еще больше, чем в период учетных работ, приходящихся на начало вылупления птенцов. К этому времени к гнездованию приступают наиболее поздно сформировавшиеся колонии, что позволяет провести полноценные учетные работы. Многолетние работы в разнообразных условиях показали, что такое гнездование является адаптацией птиц к освоению нестабильных водно-болотных экосистем [Мельников, 1981а].

Размножение мелкими колониями в чрезвычайно изменчивых условиях речных долин с горно-пойменным водным режимом обеспечивает освоение максимального количества пригодных для гнездования стаций. В то же время они не всегда расположены в удачных местах. В случае быстрого и сильного подъема уровня воды может погибнуть большое их количество, а успешность размножения снизится до критического уровня. В таких условиях большое значение имеет следующая адаптация - повторное размножение птиц, потерявших кладки в первой половине 
насиживания [Мельников, 1981a; Mel'nikov, 1992]. Птицы подселяются сразу большими группами в колонии, в которых сохранилась хотя бы часть гнезд. Вероятность их полной гибели, при повторении этой ситуации, значительно снижается, что ведет к общему повышению успешности размножения колониальных видов.

Следовательно, сохранившиеся колонии являются «информационными центрами», выполняющими сразу две функции. С одной стороны, они рекламируют наиболее продуктивные участки, являющиеся центрами «кормовой активности», а с другой - облегчают поиск мест, обеспечивающих успешное размножение. Следовательно, в нестабильных условиях среды пространственная структура колониальных птиц формируется методом «проб и ошибок». Это, вероятно, наиболее приемлемый способ реализации потенциальных возможностей любого вида к выживанию в подобных условиях. Несомненно, у неколониальных видов птиц работают эти же механизмы формирования оптимальной пространственной структуры. Однако одиночное гнездование не позволяет быстро реагировать на меняющиеся условия среды и быстро занимать оптимальные участки сразу большой группой птиц. В этом отношении колониальные виды птиц, особенно в связи с синхронным размножением больших групп, имеют явное преимущество при освоении продуктивных, но очень нестабильных водно-болотных экосистем.

Существует мнение, что колониальность не видовой признак, а свойство осваиваемой видом экологической ниши [Хлебосолов, 1990; Wynne-Edwards, 1962; Lack, 1968]. Конечно, если исходить из плотности гнездования как основного признака колонии, можно прийти и к такому выводу, ведь практически все виды могут формировать в определенных условиях плотные гнездовые агрегации. Однако детальное изучение видов, принадлежность которых к колониальным не вызывает сомнения, указывает на присутствие специфических адаптаций, свойственных только колониальным птицам, в частности высокая синхронность гнездования в простых (небольших) колониях, агрессивные воздушные защитные реакции (при отсутствии наземных отвлекающих демонстраций), специфическая динамика пространственной структуры [Мельников, 1981a; 2006б; 2013; McNichol, 1975; Mel'nikov, 1985; 1998]. В связи с этим есть смысл рассмотреть специфику их экологии, связанную с трофическими отношениями в биоценозе.

Специальное изучение трофических взаимоотношений колониальных и неколониальных видов птиц в дельте р. Селенги показало преимущественное использование ими только определенных кормовых объектов. Для водоплавающих птиц (неколониальная группа видов) наиболее характерно использование семян растений и их вегетативных частей (только в летний период). Из животных кормов наибольшее значение в питании уток имеют компоненты прибрежных биоценозов - личинки насекомых, моллюски и гаммариды. Имаго насекомых встречаются редко и в незначительном количестве. Следовательно, рассмотренные нами неколониальные виды птиц являются преимущественно растительноядными видами [Скрябин, 1975; Толчина и др., 1978]. В питании чайковых птиц (группа колониальных видов) явно преобладают животные корма, а растительные встречаются редко и только у крупных видов, склонных к синантропизации (монгольская и сизая чайки) [Липин и др., 1979]. Они хорошо разделяются на преимущественно насекомоядных (малая и озерная 
Ю. И. Мельников. Лимитирующие факторы и успешность размножения околоводных и водоплавающих птиц в условиях горно-пойменного водного режима в дельте...

чайки, белокрылая и белощекая крачки) и рыбоядных птиц (монгольская и сизая чайки, чеграва). Речная крачка занимает промежуточное положение и отличается ярко выраженной сезонной сменой питания. По летнему питанию она относится к насекомоядным, а весеннему и осеннему — к рыбоядным видам птиц. В целом питание изученных колониальных видов птиц зависит от обилия и доступности кормовых объектов [Скрябин, Размахнина, 1978].

Оценивая эти отношения, необходимо отметить, что изученные виды сразу четко делятся на две группы птиц: питающиеся неподвижными или малоподвижными кормовыми объектами и использующие в питание активно перемещающиеся кормовые объекты. Если питание неподвижными и малоподвижными объектами требует поиска наиболее продуктивных участков, сохраняющихся долгое время (во всяком случае на период насиживания кладок и выращивания молодняка), то для питания активными объектами (рыбы и насекомые) необходимы постоянные перемещения в пространстве, независимо от стадии гнездового цикла. Изменения погоды, ветреные, а особенно штормовые дни, изменения уровня воды, сезон года, вносят свои коррективы в распределение кормовых объектов, нередко даже в течение одного дня. Кроме того, скопления таких кормовых объектов часто очень кратковременные и они быстро меняют свое расположение в пространстве.

В связи с этим виды, питающиеся такими объектами, должны очень быстро реагировать на их распределение по территории и достаточно быстро хорошо находить в районе колоний. Поэтому их пространственная структура должна быть динамичной, а колонии располагаться в местах кратковременного обилия пищи. Это особенно важно в гнездовой период, когда пуховые птенцы требуют повышенной заботы родителей. Именно поэтому колонии отличаются высокой синхронизацией размножения, позволяющей использовать кратковременные концентрации пищи (однако достаточно продолжительные, для того чтобы успевать выращивать птенцов), а также высокой агрессивностью особей для их защиты в легко обнаруживаемых и доступных поселениях. Следовательно, колониальность ряда видов пресноводных водоемов обусловлена необходимостью использования обильных, но неравномерно распределенных и быстро меняющих расположение в пространстве кормовых объектов.

\section{Заключение}

Дельта р. Селенги отличается специфическими условиями обитания околоводных и водоплавающих птиц, среди которых в качестве лимитирующих факторов основное значение имеют колебания гидрологического режима, высокая гибель яиц от факультативных хищников и, в отдельных случаях, антропогенного влияния. Тем не менее успешность размножения птиц достаточно высока - в среднем $33,5-58,9$ \% от количества отложенных яиц. Обращает на себя внимание высокая изменчивость успешности размножения разных видов, среди как колониальных, так и неколониальных птиц. В целом репродуктивный успех колониальных видов выше, чем у неколониальных птиц, в среднем на 9,0\%. Используемые этими группами виды адаптации к гнездованию в нестабильных условиях среды, несмотря на значительные различия в экологии, одинаковы. Однако у колониальных видов они работают несколько эффективнее. Это позволяет, путем накопления незначи- 
тельных положительных результатов в гнездовой жизни птиц, за счет использования обычных для околоводных птиц адаптаций, увеличивать успешность размножения на достаточно значимую величину — от 5,0 до 15,0-20,0\% у разных видов.

Основными адаптациями колониальных видов птиц при гнездовании в чрезвычайно динамичных условиях среды являются гнездование небольшими колониями, отличающимися высокой синхронизацией размножения и высокая динамичность пространственной структуры. На оптимальных для гнездования участках они могут быстро формироваться в крупные колонии, поскольку сохранившиеся при затоплении территории группы гнездящихся птиц одновременно являются своеобразными «информационными центрами». Они значительно облегчают птицам, приступающим к повторному гнездованию, поиск мест, наиболее пригодных для размножения. Такие сохранившиеся колонии рекламируют наиболее продуктивные участки, являющиеся центрами «кормовой активности», и одновременно облегчают поиск мест, обеспечивающих успешное гнездование.

Колониальность птиц на пресноводных водоемах является эффективной репродуктивной стратегией, обеспечивающей использование обильных, но неравномерно распределенных и постоянно перемещающихся в пространстве кормовых объектов.

\section{Литература}

Бекман Л.К., Мизандронцев И.Б. О связи между распределением бентоса и органического вещества в осадках // Лимнология придельтовых пространств Байкала.Л.: Наука, 1971. С. $127-132$

Власова Л.К. Речные наносы бассейна озера Байкал.- Новосибирск: Наука, 1983.$132 \mathrm{c}$.

Гилевич А. Л. Размножение озерной чайки в дельте р. Селенги на Байкале // Экология птиц Восточной Сибири. - Иркутск: Изд-во ИГУ, 1977. — С. 37-58.

Глушенков О.В. О недейственности активных форм коллективной защиты колониальных птиц // Теоретические аспекты колониальности у птиц. - Ростов-н/Д: Изд-во ЮНЦ PAH, 2012.- C. 57-69.

Журавлев В.Е. Определение хищничества черной вороны по остаткам яиц жертв // 4-я межвуз. конф. молодых ученых: тез. докл. - Иркутск: Изд-во ИГУ, 1986. - Ч. 2. - С. 56.

Закс Л. Статистическое оценивание. - М.: Статистика, 1976.- 598 с.

Зубакин В.А. Роль различных факторов в возникновении и развитии колониальности у чайковых птиц // Колониальность у птиц: структура, функции, эволюция. - Куйбышев: Изд-во КГУ, 1983.- С. 37-64.

Иметхенов А.Б. Катастрофические явления в береговой зоне Байкала. - Улан-Удэ: Изд-во БурПГИ, 1994.- 65 с.

Липин С.И., Сонин В. Д., Дурнев Ю.А. О синантропизации чаек (Laridae) в Восточной Сибири // Экология птиц бассейна оз. Байкал. - Иркутск: Изд-во ИГУ, 1979. — C. 91-100.

Мельников Ю.И. Экология белокрылой крачки Восточной Сибири // Экология птиц Восточной Сибири. - Иркутск: Изд-во ИГУ, 1977. - С. 59-92.

Мельников Ю. И. Крупные чайки и их влияние на успешность размножения приводных птиц в дельте р. Селенги // Проблемы экологии Прибайкалья. IV. Популяционные аспекты экологии (тез. докл.). - Иркутск: Изд-во ИГУ, 1979. - С. 75-76.

Мельников Ю.И. Динамика пространственной структуры колониальных птиц в нестабильных условиях среды // Материалы Х Прибалт. орнитол. конф.- Рига: Изд-во Ин-та биологии АН Латв.ССР, 1981a.— Т. 2.- С. 107-110. 
Ю. И. Мельников. Лимитирующие факторы и успешность размножения околоводных и водоплавающих птиц в условиях горно-пойменного водного режима в дельте...

Мельников Ю.И. Изменчивость популяционно-демографических параметров некоторых видов околоводных птиц // Материалы Х Прибалт. орнитол. конф.- Рига: Изд-во Инта биологии АН Латв.ССР, 1981б. - Т. 2.- С. 111-114.

Мельников Ю.И. Колония и ее критерии // Научные основы обследования колониальных гнездовий околоводных птиц. - М.: Наука, 1981в. - С. 88-90.

Мельников Ю.И. О некоторых адаптациях прибрежных птиц // Экология. - 1982. № 2. - C. 64-70 (Mel'nikov Yu. I. Certain Adaptations in Coastal Birds // The Soviet Journal of Ecology, 1982.— Vol. 13, № 2.— Р. 134-139).

Мельников Ю.И. К экологии малой чайки в дельте Селенги // Фауна и экология птиц Восточной Сибири. - Иркутск: Изд-во ИГУ, 1984.- С. 68-76.

Мельников Ю.И. О критериях колониальности у птиц // Теоретические аспекты колониальности у птиц.- М.: Наука, 1985.— С. 92-96.

Мельников Ю.И. О характере защитных реакций чайковых птиц (Laridae) // Групповое поведение животных. - Куйбышев: Изд-во КГУ, 1987.- С. 27-48.

Мельников Ю.И. Численность и распределение чайковых птиц в дельте р. Селенги (Южный Байкал) // Бюл. МОИП. Отд. биол. — 1988. - Т. 93, вып. 3.— С. 21-29.

Мельников Ю.И. Распространение и экология черной крачки на границе ареала в Восточной Сибири // Исследования по экологии и морфологии животных. - Куйбышев: Издво КГУ, 1989. - С. 46-55.

Мельников Ю.И. Трофические стратегии и хищничество у серебристой чайки // Серебристая чайка. Распространение, систематика, экология.- Ставрополь: Северо-Кавказск. отд. МОО РАН, 1992.- С. 103-105. 32.

Мельников Ю.И. О статусе колонии у птиц // Вестн. ИрГСХА, 1997.—- Вып. 6. — С. 19-

Мельников Ю.И. Гнездовые скопления неколониальных видов птиц и основные закономерности их формирования // Охрана и рациональное использование животных и растительных ресурсов.- Иркутск: Изд-во ИрГСХА, 2000.- С. 249-259.

Мельников Ю.И. Особенности формирования колоний белощекой крачки (Chlidonias hybrida) в нестабильных условиях среды // Тр. госзаповедника «Байкало-Ленский», - 2003а. - Вып. 3.- С. 94-97.

Мельников Ю.И. Синхронизация размножения и ее роль в эволюции колониальности у птиц // Биологическая наука и образование в педагогических вузах. - Новосибирск: Издво НГПИ, 2003б. - Вып. 3.- С. 105-112.

Мельников Ю.И. Термин «экологическая ситуация» и его использование при специальных исследованиях // Современные проблемы орнитологии Сибири и Центральной Азии. - Улан-Удэ: Изд-во БГУ, 2006а. — Ч. 1.— С. 56-59.

Мельников Ю.И. Популяционный гомеостаз в репродуктивный период (на примере околоводных и водоплавающих птиц) // Развитие современной орнитологии в Северной Евразии. - Ставрополь: Изд-во СГУ, 2006б.- С. 316-334.

Мельников Ю.И. Особенности размножения белощекой крачки (Chlidonias hybrida) в условиях нестабильного гидрологического режима // Сибирская орнитология (Вестн. БГУ, специальная серия).— Улан-Удэ: Изд-во БГУ, 2006в. - Вып. 4. - С. 163-187.

Мельников Ю. И. Гидрологический режим водоемов как экологический фактор (на примере дельты реки Селенги) // Охрана и научные исследования на особо охраняемых природных территориях Дальнего Востока и Сибири.- Хабаровск: Изд-во Приамурск. ГО, 2007a.- C. 137-148.

Мельников Ю.И. Адаптации прибрежных птиц к гнездованию на высокопойменных лугах Прибайкалья // Структура, функционирование и охрана природной среды.- УланУдэ: Изд-во БГУ, 2007б.- С. 68-73. 
Мельников Ю.И. Колониальность у птиц: проблемы, подходы, практика // Вісник Запорізького національного університету. — 2008. - № 1.— С. 152-162.

Мельников Ю.И. Экология водоплавающих птиц в дельте р. Селенги: динамика обводненности территории и распределение по биотопам // Байкал. зоол. журн. - 2009а. № 2.- С. 49-60.

Мельников Ю.И. Динамика климата и многолетняя изменчивость успешности размножения водоплавающих птиц в дельте р. Селенги // Климат, экология и сельское хозяйство Евразии.- Иркутск: Изд-во ИрГСХА, 2009б.- С. 149-165.

Мельников Ю.И. Структура ареала и экология азиатского бекасовидного веретенника Limnodromus semipalmatus (Blyth, 1848). - Иркутск: НЦРВХ СО РАМН, 2010а. — 284 с.

Мельников Ю.И. Хищничество чайковых птиц в дельте р. Селенга (Южный Байкал): новая трофическая стратегия в изменчивых условиях среды // Вестн. ИрГСХА. - 2010б.Вып. 41.- С. 57-69.

Мельников Ю.И. Водоплавающие птицы Прибайкалья: пространственная структура и успешность размножения // Изв. Иркутск. гос. ун-та. Сер. Биология. Экология. 2010в. - Т. 3, № 1.- С. 49-59.

Мельников Ю.И. Избирательность гнездовых стаций у водоплавающих птиц и ее причины // Изв. Иркутск. гос. ун-та. Сер. Биология. Экология. - 2010. - Т. 3, № 4. - С. 65-69.

Мельников Ю. И. Компенсационное размножение околоводных и водоплавающих птиц: выделение повторных кладок на основе материалов полевых наблюдений // Изв. Иркутск. гос. ун-та. Сер. Биология. Экология. — 2011а.— Т. 4, № 3.- С. 41-53.

Мельников Ю.И. Мезо- и микрорельеф территории как экологический фактор, определяющий пространственное распределение птиц водно-болотных экосистем (на примере дельты р. Селенги) // Народное хозяйство. — 2011б. - № 2.— С. 224-234.

Мельников Ю.И. Повторное (компенсационное) размножение и популяционный гомеостаз (на примере околоводных и водоплавающих птиц) // Современные проблемы эволюции. Любищевские чтения - 2011 (Ульяновск, Россия, 5-7 апреля 2011 г.). - Ульяновск: Изд-во УлГПУ, 2011в.- С. 383-391.

Мельников Ю.И. Элементарная рассудочная деятельность животных как феномен эволюции (на примере околоводных и водоплавающих птиц) // Развитие жизни в процессе абиотических изменений на Земле.- Иркутск: Изд-во Ин-та географ. им. В. Б. Сочавы, 2011. - С. 132-143.

Мельников Ю.И. Адаптация околоводных и водоплавающих птиц к гнездованию в условиях динамичного гидрологического режима: достройка гнезд по мере подъема уровня воды // Бюл. МОИП. Отд. биол. - 2012а. - Т. 117, вып. 2.- С. 3-15.

Мельников Ю. И. Динамика успешности размножения водоплавающих птиц на разных фазах 11-летнего климатического цикла (дельта р. Селенги, Южный Байкал) // Изв. Самар. научного центра РАН. — 20126. - Т. 14, № 1(8).- С. 1907-1911.

Мельников Ю.И. Синхронизация размножения в колониях чайковых птиц (на примеpe белощекой крачки Chlidonias hybrida) // Современные проблемы эволюции. Любищевские чтения - 2012 (Ульяновск, Россия, 5-7 апреля 2012 г.). - Ульяновск: Изд-во УлГПУ, 2012в.- С. 254-262.

Мельников Ю.И. Плотность гнездования колониальных видов птиц как феномен эволюции // Теоретические аспекты колониальности у птиц: материалы III совещ.- Ростов-н/Д: Изд-во ЮНЦ РАН, 2012. - С. 92-103.

Мельников Ю.И. Экология речной крачки Sterna hirundo L., 1758 дельты р. Селенга (озеро Байкал): величина колоний, синхронизация и успешность размножения // Современные проблемы эволюции и экологии. Любищевские чтения - 2013 (Ульяновск, Россия, 5-7 апреля 2013 г., ).— Ульяновск: Изд-во УлГПУ, 2013.— С. 390-399. 
Ю. И. Мельников. Лимитирующие факторы и успешность размножения околоводных и водоплавающих птиц в условиях горно-пойменного водного режима в дельте...

Мельников Ю.И. Эволюция колониальности у птиц: пути и подходы к решению проблемы // Современные проблемы эволюции и экологии. Любищевские чтения - 2014 (Ульяновск, Россия, 7-9 апреля 2014 г.).— Ульяновск: Изд-во УлГПУ, 2014a.- С. 101-117.

Мельников Ю.И. Восстановление хода размножения азиатского бекасовидного веретенника Limnodromus semipalmatus (Blyth, 1848) с использованием флотационного метода // Изв. Иркутск. гос. ун-та. Сер. Биология. Экология. — 2014б.— Т. 10. - С. 24-41.

Мельников Ю.И. Гетерогенность водно-болотных экосистем и ее связь с популяционными параметрами птиц // Современные проблемы эволюции и экологии. Любищевские чтения - 2016 (Ульяновск, Россия, 5-7 апреля 2016 г.). - Ульяновск: Изд-во УлГПУ, 2016. - С. 78-89.

Мельников Ю.И. Отвлекающие демонстрации речных уток в гнездовой период (подсемейство Anatinae) и их роль в сохранении кладок // Успехи современной науки. - 2017а. Т. 9, № 4.- С. 50-57.

Мельников Ю. И. Отвлекающие демонстрации нырковых уток (подсемейство Aythynae) в условиях интенсивного давления хищников // Успехи современной науки. — 2017б.№ 7.- С. 59-63.

Мельников Ю.И. Долины рек с горно-пойменным водным режимом как специфическая среда обитания птиц // Современные проблемы орнитологии Сибири и Центральной Азии.- Иркутск: Изд-во ИНЦХТ, 2018. - С. 135-139.

Мельников Ю.И., Садков В.С. Материалы по биологии размножения речной крачки оз. Байкал // Экология птиц Восточной Сибири. - Иркутск: Изд-во ИГУ, 1977. - С. 92-109.

Мельников Ю.И. Лысиков С.И. О хищничестве чайковых птиц на Южном Байкале // Бюл. МОИП. Отд. биол. - 1983. - Т. 88, вып. 5. - С. 21-28.

Мельников Ю.И., Захаров С.К., Коневин С.Г. Плотность гнездования и успешность размножения в локальных группах лысухи // Охрана и воспроизводство животных в Прибайкалье.- Иркутск: Изд-во ИСХИ, 1987.- С. 29-36.

Мельников Ю. И., Мельникова Н. И. Серебристая чайка и особенности изучения ее роли в экосистемах // Серебристая чайка. Распространение, систематика, экология.- Ставрополь: Изд-во Северо-Кавказск. отд-ния МОО РАН, 1992.— С. 105-108.

Мельников Ю. И., Коневин С. Г., Захаров С. К., Шинкаренко А. В., Подковыров В. А. Экология лысухи в дельте р. Селенги // Экология позвоночных животных Восточной Сибири.- Иркутск: Изд-во ИГУ, 1983.- С. 25-44.

Мельников Ю.И., Шинкаренко А.В., Подковыров В.А., Мельникова Н.И., Лысиков С.И. Некоторые аспекты гнездования водоплавающих в колониях чайковых птиц на Южном Байкале // Фауна и экология птиц Восточной Сибири. - Иркутск: Изд-во ИГУ, 1984.- C. 52-68.

Мельников Ю.И., Шинкаренко А.В., Подковыров В.А., Журавлев В.Е., Коневин С.Г. Материалы по экологии серой цапли в дельте реки Селенги // Климат, экология и сельское хозяйство Евразии. - Иркутск: Изд-во ИрГСХА, 2009. — С. 204-212.

Михантьев А.И. Некоторые эколого-этологические механизмы регуляции численности утиных в природе и возможности их использования в биотехнии // Теоретические основы и практические работы в Сибири. - Новосибирск: Наука, 1980.- С. 146-190.

Онно С. Время гнездования у водоплавающих и прибрежных птиц в Матсалуском заповеднике // Сообщ. Прибалт. комиссии по изучению миграций птиц.- Рига: Зинатне, 1975. - № 8.- С. 107-155.

Паевский В. А. Демография птиц.- Л.: Наука, 1985.- 285 с.

Панов Е.Н. Поведение животных и этологическая структура популяций.- М.: Наука, 1983. - $423 \mathrm{c}$. 
Подковыров В.А. Экология водоплавающих птиц Байкала в условиях антропогенной трансформации водно-болотных биоценозов: автореф. дис. ... канд. биол. наук.- Иркутск: Изд-во ИГУ, 1997.- 18 с.

Скрябин Н.Г. Водоплавающие птицы Байкала. - Иркутск: Вост-Сиб. кн. изд-во, 1975. - 244 c.

Скрябин Н. Г., Размахнина, О. В. Питание чаек и крачек Байкала // Роль птиц в биоценозах Восточной Сибири. - Иркутск: Изд-во ИГУ, 1978.- С. 4-52.

Тихонов А.В., Фокин С. Ю. Защитные реакции ржанкообразных птиц в гнездовой период // Орнитология.-1982.- Вып. 17.- С. 54-65.

Толчина С.Н., Скрябин Н.Г., Толчин В.А. Питание водоплавающих птиц Байкала // Роль птиц в биоценозах Восточной Сибири. - Иркутск: Изд-во ИГУ, 1978. - С. 52-99.

Фефелов И. В. Роль гидрологического режима дельты реки Селенги в динамике населения уток: автореф. дис. ... канд. биол. наук. - Иркутск: Изд-во ИГУ, 1996. - 18 с.

Фефелов И. В., Шинкаренко А. В., Подковыров В. А. Динамика популяций уток в дельте Селенги // Рус. орнитол. журн. - 1995. Т. — 4, № 1/2. - С. 45-53.

Фефелов И. В., Тупицын И. И., Подковыров В. А., Журавлев В. Е. Птицы дельты Селенги: Фаунистическая сводка.- Иркутск: Вост.-Сиб. изд. компания, 2001. - 320 с.

Флинт В.Е. Отвлекающие демонстрации у птиц: биологический и этологический аспекты (на примере куликов) // Адаптивные особенности и эволюция птиц.- М.: Наука, 1977.- С. 109-119.

Харитонов С. П. К вопросу о развитии колониальности у птиц // Колониальность у птиц: структура, функции, эволюция. - Куйбышев: Изд-во КГУ, 1983.- С. 93-104.

Хлебосолов Е.И. Колониальность - видовой признак или свойство ниши // Современные проблемы изучения колониальности у птиц. - Симферополь; Мелитополь: Сонат, 1990.- C. 49-51.

Черничко И.И. Вероятные пути возникновения колониального гнездования у птиц (на примере ржанкообразных) // Колониальность у птиц: структура, функции, эволюция.Куйбышев: Изд-во КГУ, 1983.- С. 64-93.

Шинкаренко А.В. К вопросу о кольцевании утиных в Восточной Сибири // Первая конф. молодых ученых. - Иркутск: Изд-во ИГУ, 1983.- С. 32-33.

Шинкаренко А.В., Подковыров В.А. Успешность размножения водоплавающих птиц в дельте Селенги при низком уровне воды // Экология гнездования птиц и методы ее изучения: тезисы докл. молодых ученых. - Самарканд: Изд-во СамГУ, 1979. - С. 239-240.

Armstrong E. A. Bird Display. - Cambridge: Cambridge Univ. Press, 1947. - 118 p.

Brown Ch.R., Brown M. B. Avian coloniality. Progress and Problems // Current Ornithology. New York: Kluwer Academic Publ., 2001.— Vol. 16. - P. 1-82.

Darling F. F. Bird flocks and the breeding cycle.- Cambridge: Cambridge University Publ., 1938. - $124 \mathrm{p}$.

Emlen S. T., Demong N. J. Adaptive significance of synchronized breeding in a colonial bird: a new hypothesis // Science. — 1975. - Vol. 188. — P. 1029-1031.

Lack D. Ecological Adaptations for Breeding in Birds. - London: Chapman and Hall Publ., 1968.- $161 \mathrm{p}$.

Mayfield H. Nesting success calculated from exposure // Wilson Bull. — 1961._ Vol. 73._ P. 255-261.

Mayfield H. Suggestions for calculating nest success // Wilson Bull. — 1975. — Vol. 87._ P. 456-466.

McNichol M. K. Larid site tenacity and group adherence in relation to habitat // Auk. - 1975. - Vol. 92, № 1.— P. 98-104. 
Ю. И. Мельников. Лимитирующие факторы и успешность размножения околоводных и водоплавающих птиц в условиях горно-пойменного водного режима в дельте...

Mel'nikov Yu. I. Adaptive features of colonial nesting under fluctuating environmental conditions // Acta XYIII Congressus Internationalis Ornithologicus. - M.: Nauka, 1985.— Vol. 2.- P. 1140-1141.

Mel'nikov Yu. I. Compensative Reproduction and Its Role in population Dynamics of Waterfowl // Proc. $9^{\text {th }}$ International Waterfowl ecology symposium. - Hajduszoboszlo, 1992. P. 25-26.

Mel'nikov Yu. I. The Game Waterfowl and biodiversity indicators of the Wetlands in East Siberia // Gibier Faune Sauvage, Game Wildl.: Proc. of the IUGB XXIIIrd Congress, 1998. Vol. 15. - Part 2 (Special number). - P. 683-692.

Nisbet I. C.T. Selective effects of predation in a tern colony // Condor. - 1975. - Vol. 77, № 2.- P. 221-226.

Shaffer T.L. A unified approach to analyzing nest success // The Auk. - 2004. - Vol. 121, № 2.- P. 526-540.

Simmons K.E.L. The Nature of the predator - reactions of waders towards humaus, with special reference to the Role of the aggressive-, escape-, and blooding-drives // Behaviour. 1955. - Vol. 8. - P. 130-173.

Waddington C.H. Canalization of development and the inheritance of acquired characters // Nature. 1942.— Vol. 150, № 1247. - P. 563-565.

Westerskov K. Method for determining the age of game birds eggs. J. Wildlife Management. 1950.— Vol. 14, № 1.- P. 56-57.

Willson M.F. Avian community organization and habitat structure // Ecology. — 1974. Vol. 55.- P. 1017-1029.

Wittenberger J.F., Hant G.L. The adaptive significance of coloniality in birds // Current Ornithol. - 1985.— № 8.— P. 2-77.

Wynne-Edwards V. C. Animal dispersion in relation to social behavior. - Edinburgh-London: Oliver and Boyd Publ., 1962._- 653 p.

\section{LIMITING FACTORS AND BREEDING SUCCESS OF SEMIAQUATIC \\ AND AQUATIC BIRDS IN THE CONDITIONS OF MOUNTAIN-FLOODPLAIN \\ WATER REGIME IN THE SELENGA RIVER DELTA \\ (EASTERN SIBERIA)}

Yu. I. Melnikov

Yuriy I. Melnikov

Cand. Sci. (Biol.),

Baikal Museum of Irkutsk Scientific Center

1 Akademicheskaya St., Irkutsk Oblast, Listvyanka 664520, Russia

E-mail: yumel48@mail.ru

The Selenga river delta is characterized by the specific living conditions of semiaquatic and aquatic birds. Based on many years of work (1972-1985), we have revealed the limiting factors determining the breeding success of the birds in the Selenga river delta (Lake Baikal). Valley of the river has a well-defined mountain-floodplain water regime. Very strong changes in water levels during one nesting season between the periods of laying and hatching lead to significant loss of clutches, which decrease the breeding success of birds. Only the use of special adaptations (sideways building, repeat breeding and high dynamic spatial structure) 
allows birds to maintain a sufficient level of breeding. We revealed the peculiarities of bird breeding during the small (11-year) intra-century climate cycle in 1973-1982 on a key site in the central part of the Selenga river delta with an area of about $100 \mathrm{~km}^{2}$. To determine all the parameters of the nesting cycle of birds, we used nest control at discount areas of different sizes and configurations, but not less than 1.0 ha, which allowed recording the death of eggs in clutches and the emergence of new nests. The article identified the main limiting factors that determine the success of nesting season of different bird species in the conditions of mountain-floodplain water regime. In general, the reproductive success of colonial species is higher than that of non-colonial birds, an average of $9.0 \%$. The types of adaptation to nesting used by these groups under unstable environmental conditions, despite significant differences in ecology, are the same. However, in colonial species they work more efficiently. The total death of eggs in different species by season was $29.8-75.8 \%$ and was associated with the size of a particular species and the characteristics of its ecological niche.

The main adaptations of colonial bird species during nesting under extremely dynamic environmental conditions are nesting in small colonies, characterized by high synchronization of reproduction and high dynamic spatial structure. Large colonies can be quickly formed in areas optimal for nesting, since the groups of nesting birds that survived during the flooding of the territory are at the same time a kind of "information centers". Such surviving colonies advertise the most productive sites, which are the centers of "feed activity" and at the same time facilitate the search for places that ensure successful nesting. Coloniality of birds in freshwater bodies of water is an effective reproductive strategy, ensuring the use of plentiful, but unevenly distributed and constantly moving feed objects in space.

Keywords: semiaquatic and aquatic birds; nesting period; limiting factors; the magnitude of the death of nests and chicks; breeding success. 